\title{
Schuldenaanpak voor een schuldenvrije generatie
}

\author{
In maart 2019 startte de gemeente Rotterdam met een nieuwe schuldenaanpak. De focus ligt op \\ het voorkomen van schulden, schulden onder controle krijgen, meer samenwerking en innovatieve \\ oplossingen. Volgens Anne Coenen, directeur Maatschappelijke Ontwikkeling, gemeente Rotterdam, \\ is er echt iets op gang gekomen.
}

DOOR Chivra Guddens, Michiel Noordermeer en Miranda Spek

E en op de vijf Rotterdamse huishoudens heeft problematische schulden, variërend van 15.000 tot 30.000 euro. ${ }^{1}$ De gemiddelde schuld van Rotterdammers die zich melden bij de Kredietbank Rotterdam is 45.000 euro. Tijdens de begeleiding naar een schuldregelingstraject haakt een groot deel af. Er lopen in Rotterdam zo'n 60.000 mensen risico op geldproblemen. Voorkomen is dus beter dan genezen. Maar juist het voorkomen van schulden door er sneller bij te zijn, is misschien wel het ingewikkeldste van de schuldenaanpak. Voor veel mensen, jong en oud, is het hebben van schulden nog altijd een taboe. Iets waarvoor je je schaamt en waarover je niet met anderen praat, zeker niet met de overheid. Ook in Rotterdam wachten veel mensen met schulden gemiddeld vijf jaar voor ze hulp zoeken. Vaak is hun schuld in de tussentijd ruim tien keer zo hoog geworden.

\section{Schaamte opzijzetten}

Door aan te sluiten bij de landelijke campagne 'Kom uit je schuld' doorbreekt de gemeente het taboe rondom schulden. Het Rotterdamse gezicht van 'Kom uit je schuld' is de 28-jarige Donovan Felter. Als zzp'er vraagt hij een familievriend zijn belastingaangifte te doen. Elk kwartaal geeft hij hem geld, maar hij checkt nooit of alles klopt. Per toeval komt hij erachter dat de Belastingdienst hem een aanslag heeft gestuurd van meer dan 5000 euro. De familievriend blijkt met de noorderzon vertrokken en Donovan zit met een fikse schuld opgescheept. Voor de campagne vertelt hij hoe hij zijn schaamte opzijzette en hulp zocht bij een vriendin. Jongeren roept hij op om voor een goede, gezonde financiële huishouding altijd vooruit te kijken.

\section{Andere aanpak}

'Als gemeente hebben we in het verleden al veel geprobeerd om het ingewikkelde probleem van schulden aan te pakken, maar met onvoldoende resultaat', vertelt Anne Coenen. 'Dit college, met Michiel Grauss als wethouder voor de schuldenaanpak, is ervan overtuigd dat er een wezenlijk andere strategie nodig is. Daarom hebben we in maart 2019 op de resetknop gedrukt. Met ons nieuwe uitvoeringsplan 'Reset Rotterdam' richten we ons niet alleen op Rotterdammers met schulden, maar we zoeken ook actief de samenwerking

\section{Voorbeeldcasus}

De 23-jarige $V$ heeft een intakegesprek bij de gemeente Rotterdam. Hij is doorverwezen door het Jongerenloket om aan de gang te gaan met zijn schuld van ruim 25.000 euro. Onderuitgezakt op zijn stoel, met een blik van 'ik moet hier komen dus zeg jij het maar...', kijkt hij zijn nieuwe trajectbegeleider aan. Het gesprek komt maar moeilijk op gang en op de vragen die hem gesteld worden, antwoordt hij alleen met ja of nee. Als $V$ op zijn derde afspraak nog steeds hetzelfde onbeholpen gedrag vertoont, is voor zijn trajectbegeleider de grens bereikt. Er volgt een pittig gesprek waarin hij $V$ niet alleen op zijn houding en verantwoordelijkheid wijst, maar ook duidelijk maakt dat ze zijn problemen alleen samen kunnen oplossen. Tijdens de volgende afspraken merkt de trajectbegeleider dat er iets doorbroken is. $V$ is beleefd, minder gestrest, werkt mee, gaat aan de slag met zijn schuldeisers en belt als hij ergens niet uitkomt. Het contact tussen de twee verloopt steeds soepeler en $V$ beseft wat een zooitje hij ervan gemaakt heeft. Zijn schulden, die bestaan uit verkeersboetes, torenhoge telefoonrekeningen en een fikse achterstand bij zijn zorgverzekering, beginnen pijn te doen. $V$ neemt steeds meer zijn verantwoordelijkheid, ook tegenover zijn moeder, bij wie hij nog steeds inwoont. In zijn financieel budget neemt hij ook een bedrag op voor kostgeld. Inmiddels heeft $\mathrm{V}$ weer grip op zijn leven. Hij heeft een baan, zit in een traject bij de gemeentelijke kredietbank en kan over drie jaar schuldenvrij zijn. Zijn trajectbegeleider Chris Maarssen van de Kredietbank Rotterdam is trots op hem. 'Dit is een mooi voorbeeld dat onze stress-sensitieve dienstverlening werkt. We laten iemand niet meer los totdat er een traject in gang is gezet.' 


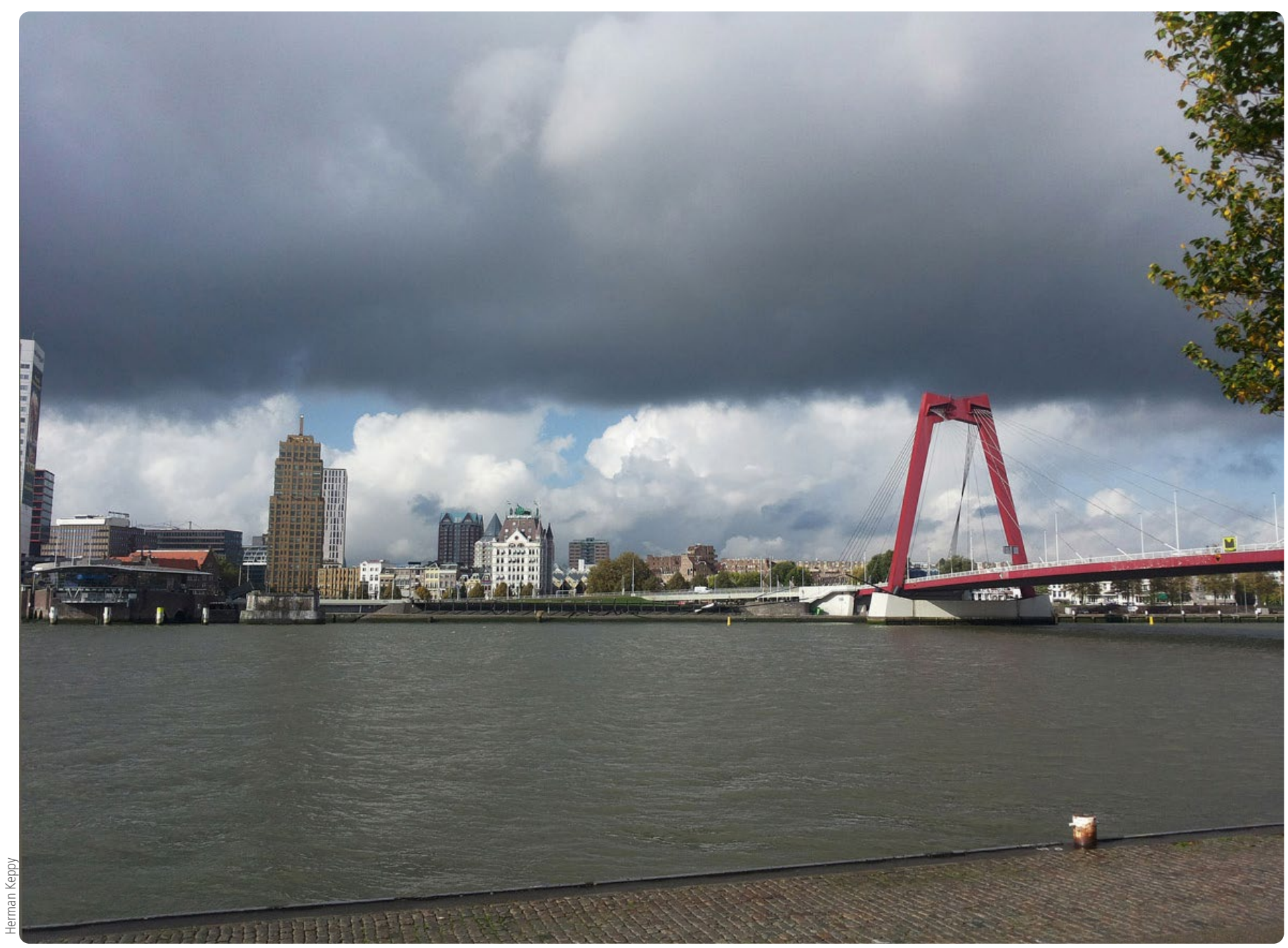

op met bewindvoerders, deurwaarders, de rechtbank en woningcorporaties. De hele "schuldenindustrie", zeg maar. Voor eind 2021 gaan we 15.000 Rotterdammers helpen hun schulden onder controle te krijgen.' Dat de aanpak effect heeft, blijkt uit het feit dat vorig jaar ruim 3.500 huishoudens een individueel ondersteuningsplan hebben gekregen. Duizend meer dan in 2018.

\section{Belangrijke pijlers}

Met 'Reset Rotterdam' pakt de gemeente schulden op een nieuwe manier aan. Wat doen ze anders dan voorheen? 'Er is veel meer aandacht voor het voorkomen van schulden', legt Coenen uit. 'Vroegsignalering is een van onze pijlers. Vooral bij jongeren tussen de 18 en 27 jaar zitten we er bovenop. Met de driejarige campagne 'Kom uit je schuld' proberen we geldproblemen bespreekbaar te maken en de schaamte te doorbreken. Ter voorkoming van escalatie van schulden werken we nauw samen met diverse partners, zoals woningcorporaties en de voedselbanken. We investeren in voorlichtingslessen op scholen en hebben recentelijk de zakgeldgids uitgebracht, die ouders kunnen gebruiken om hun kinderen met geld te leren omgaan. De tweede pijler is stress-sensitieve dienstverlening. We kiezen voor een positieve bejegening van Rotterdammers met schulden, met vertrouwen als vertrekpunt. Verder is onze samenwerking met bewindvoerders en deurwaarders geïntensiveerd.
We hebben een aantal mooie afspraken met beschermingsbewindvoerders vastgelegd in een convenant. Ook dragen woningcorporaties, verzekeraars, energieleveranciers, scholen en ambassadeurs in de stad hun steentje bij. Zij zijn als het ware onze "partners in crime". Daar mogen we best trots op zijn!'

\section{Hulp op maat}

We hebben geconstateerd dat het onderscheid tussen 'niet willers' en 'niet

\section{Partners}

De schuldenproblematiek is hardnekkig en ingewikkeld. Om nieuwe schulden te voorkomen en de bestaande aan te pakken, zoekt de gemeente Rotterdam naar innovatieve oplossingen. Zij hebben daar het rijk bij nodig, en belangenorganisaties, onderwijsinstellingen en bedrijven. Alle mogelijke partijen wordt gevraagd om mee te denken en hun verantwoordelijkheid te nemen. Er worden contacten gelegd met schuldeisers, incassobureaus en bewindvoerders.

Schuldeisers worden daarbij niet als de veroorzakers van schulden gezien, maar vooral als partners bij het vinden van oplossingen. De meest voorkomende schuldeisers zijn de Belastingdienst, het CJIB, zorgverzekeraars en woningcorporaties. 


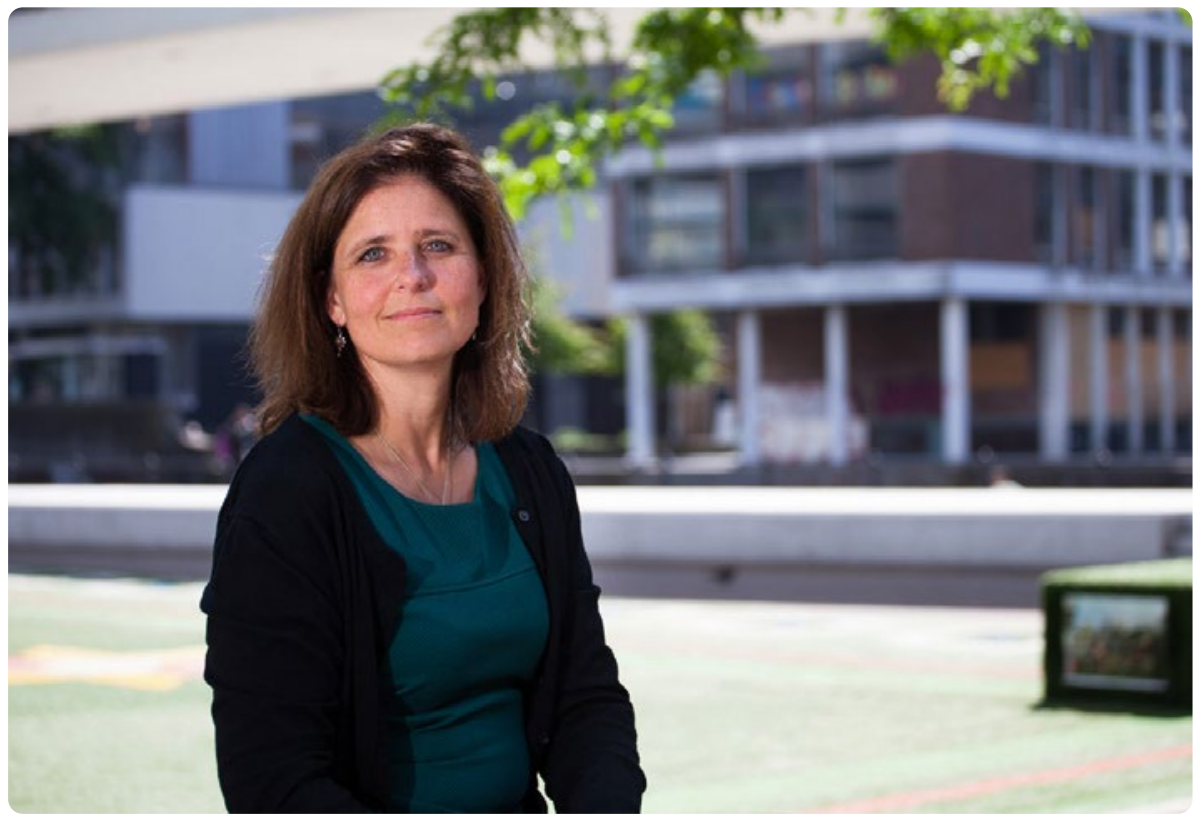

Anne Coenen: 'Voor eind 2021 gaan we 15.000 Rotterdammers helpen hun schulden onder controle te krijgen.'
In ruil hiervoor verwachten we wel een tegenprestatie zoals het afmaken van een opleiding, aan het werk gaan of een maatschappelijke stage. Soms is het nodig dat iemand ook nog een tijdje een buddy of maatje krijgt.'

\section{Coronacrisis}

En toen was daar ineens het coronavirus, dat het normale leven volledig op zijn kop zette. 'De coronamaatregelen raken iedereen in de stad', concludeert Coenen. 'Wij moesten ook ineens anders gaan werken. Geen face to face gesprekken of huisbezoeken meer. Onze trajectbegeleiders bellen hun cliënten nu en vragen hoe het gaat en of ze nog hulp nodig hebben. Daarnaast hebben we het tempo van de uitrol van de nieuwe aanpak over de gehele stad opgeschroefd, waardoor we in juni in kunners' in de praktijk niet zo zwart-wit is. Bij een grote groep schuldenaren is de wil er wel degelijk, maar lukt het door angst, moedeloosheid, taalachterstand, laaggeletterdheid of een licht verstandelijke beperking simpelweg niet. Iedereen die bij de gemeente aanklopt, krijgt nu hulp op maat. Door maatwerk te bieden, goed te luisteren naar hulpvragen en emoties en stress weg te nemen, winnen de trajectbegeleiders het vertrouwen van hun cliënten. In Rotterdam, en met name in de wijken waar veel betalingsachterstanden voorkomen, wordt nauw samengewerkt met woningcorporaties, verzekeraars en energieleveranciers om te voorkomen dat gezinnen met kinderen uit huis worden gezet of worden afgesloten van gas, water en licht.

\section{In één keer aflossen}

Een torenhoge telefoonrekening, rood staan, achterstanden bij de zorgverzekering, het terugbetalen van studiekosten; steeds meer jongeren blijven te lang

\section{'Zodra iemand bij ons aanklopt,}

\section{bieden we een maatwerkoplossing aan om de schuldenproblematiek op te lossen'}

worstelen met schulden en dat belemmert hun ontwikkeling. 'Daarom stoppen we meer energie in schuldhulp aan jongvolwassenen in de leeftijd van 18 tot 27 jaar', zegt Coenen. 'Deze groep is heel divers. Sommigen zitten nog op school, anderen werken of zorgen voor hun kinderen. Zodra iemand bij ons aanklopt, bieden we een (maatwerk) oplossing aan om de schuldenproblematiek op te lossen. In vele gevallen kan dit via het inzetten van een schuldsaneringstraject of een schuldbemiddelingstraject. Als dit niet lukt, gaan we nog een stap verder en bieden we aan de schuld af te lossen uit het perspectieffonds voor jongeren. Een fonds dat speciaal voor deze doelgroep in het leven is geroepen.

\section{Stadsmarinier Schulden}

Om de ambities van de gemeente Rotterdam te helpen realiseren en kracht bij te zetten, wordt een stadsmarinier Schulden aangesteld. Deze stadsmarinier krijgt een centrale rol in de schuldenaanpak, met name daar waar de gewone inzet niet toereikend is. De stadsmarinier kent zijn wijk, loopt veel over straat en gaat met bewoners en ondernemers in gesprek om knelpunten met eigen ogen te aanschouwen.

Deze stadsmarinier valt rechtsreeks onder de wethouder Armoede, Schuldenaanpak en Informele zorg. alle gebieden van Rotterdam actief zijn als trajectbegeleiders financiën in plaats van eind 2020. Want in tijden van crisis geldt nog meer dan anders: hoe eerder iemand hulp krijgt, hoe beter. Veel mensen maken zich zorgen over hun inkomen. Ze zijn bang hun baan te verliezen. Dat zorgt voor stress en daarom is het belangrijk dat ze zo snel mogelijk grip krijgen en houden op hun financiële situatie. Wij verwachten door corona een toename van schuldenproblematiek in Rotterdam. Wij maken ons daarom al klaar voor het scenario dat er meer mensen bij het loket voor schuldhulp zullen verschijnen. Pas volgend jaar weten we wat de precieze cijfers zijn rondom schulden en corona. We hopen natuurlijk dat dit meevalt!'

Michiel Noordermeer, beleidsadviseur schulden, gemeente Rotterdam

Chivra Guddens, communicatieadviseur schulden, gemeente Rotterdam

Miranda Spek, speechschrijver, gemeente Rotterdam

\section{Noot}

1 CBS 2019 